\title{
Coexpression of Trypsin Inhibitory and Acceleratory Substances during Autoxidation of Methyl Linolenate : Confirmation of Trypsin Inhibitory Substances
}

\author{
Hideo Hatate*1, Yoichiro Hama*2, Ryusuke TANaKA*1, Nobutaka SuZUKI*1, \\ Yasuo HataTE*3, and Yoshinobu KaWANO*4 \\ * 1 Department of Food Chemistry and Technology, National Fisheries University \\ (2-7-1, Nagatahonmachi, Shimonoseki-shi 759-6595) \\ *2 Department of Applied Biological Science, Saga University \\ (1, Honjo, Saga-shi 840-8502) \\ *3 Department of Applied Chemistry and Chemical Engineering, Kagoshima University \\ (1-21-40, Korimoto, Kagoshima-shi 890-0065) \\ * 4 Department of Material Science, Miyazaki University \\ (1-1, Gakuenkibanadai-nishi, Miyazaki-shi 889-2192)
}

\begin{abstract}
During the autoxidation of methyl linolenate, a group of degradation products capable of inhibiting $\beta$-trypsin activity were generated along with the accelerating substances, as also noted in a previous study. Chemical modification of the functional groups indicated the carbonyl and hydroxyl groups of the inhibitory degradation products and $\varepsilon$-amino group(s) of trypsin to possibly be essential for the inhibition, but hydroperoxide not necessarily involved in inhibitory activity. The inhibitory degradation products inhibited $\alpha$-chymotrypsin and lysozyme activity and thus may be inhibitors of various enzymes. There is thus the possibility that enzyme inhibitors and accelerators are generated spontaneously during the autoxidation of unsaturated lipids.
\end{abstract}

Key words : autoxidation, methyl linolenate, trypsin, chymotrypsin, lysozyme, inhibitor, accelerator

\section{Introduction}

Lipid oxidation is now recognized to be a critically important reaction in physiological processes and in food products. Toxicological researches about lipid oxidation products have been carried out both in vivo and in vitro systems, and lipid oxidation products such as lipid hydroperoxides and their secondary degradation products including 4-hydroxynonenal ${ }^{1)-3)}$ were suggested to repress enzymatic activity ${ }^{4) \sim 9)}$. We have been studied in vitro effect of oxidized unsaturated lipids on enzymes, mainly on bovine pancreatic $\beta$-trypsin ${ }^{(0) \sim 12)}$, which is advantageous for these assessments because of the well-elucidated properties such as substrate specificity, chemical structure, and inhibitors. In the previous paper $^{11)}$, we reported that a group of degradation

Corresponding author: Hideo Hatate products obtained from autoxidized methyl linolenate (oxd MLn) could significantly enhance the amidase activity of $\beta$-trypsin and, at the same time, some other degradation products appeared to depress that activity. In this study, we confirmed the coexistence of these inhibitory substances with the acceleratory ones in the degradation products of oxd MLn.

\section{Materials and Methods}

\section{$2 \cdot 1$ Separation of Active Fractions from} Autoxidized Methyl Linolenate

Four grams of MLn (Tokyo Kasei Kogyo) was oxidized for $48 \mathrm{~h}$ at $40^{\circ} \mathrm{C}$ in the dark with a gentlestirring. The resulting oxd MLn (Peroxide value Ca. $2400 \mathrm{meq} / \mathrm{kg}$ ) was separated by gel chromatography on a Sephadex LH-20 column $(2.5 \times 120$ $\mathrm{cm}$ ) using acetone as the eluent at a flow rate of 1.0 $\mathrm{ml} / \mathrm{min}$. The active fractions obtained were partially purified by a prepacked silicic acid 
chromatography (LiChroprep Si-60, $2 \times 31 \mathrm{~cm}, \mathrm{E}$. Merk) using $n$-hexane and 2-propanol (95/5, $\mathrm{vol} / \mathrm{vol}$ ) as the eluent at a flow rate of $0.5 \mathrm{ml} / \mathrm{min}^{11)}$. The active fractions obtained were allowed to react with each of enzymes under the suitable conditions and the residual enzyme activity was measured.

\section{$2 \cdot 2$ Assay of Enzymatic Activity}

$\beta$-Trypsin was isolated from bovine pancreatic trypsin (Sigma Chemical Co., $3 \times$ crystallized) by the method of Shroeder and Shaw ${ }^{13)} . \varepsilon-N$-Acetylated trypsin (Sigma Chemical Co.), bovine pancreatic $\alpha$-chymotrypsin (Sigma Chemical Co., $3 \times$ crystallized, dialyzed and lyophilized), and chicken egg white lysozyme (Sigma Chemical Co., $3 \times$ crystallized, dialyzed and lyophilized) were used as received.

After the reaction of each enzyme with oxd MLn, the residual enzymatic activity was assayed as follows. Amidase activity of $\beta$-trypsin was measured using $\alpha$ - $N$-benzoyl-DL-arginine- $p$-nitroanilide $\cdot \mathrm{HCl}$ (BAPNA, Sigma Chemical Co.) as substrate ${ }^{(0)}$. In some cases, $\alpha$ - $N$ - $p$-tosyl-L-arginine methyl ester (Sigma Chemical Co.) and milk casein (Wako Pure Chemical Ind., Ltd.) were used as the esterase and proteolytic substrates of $\beta$ trypsin ${ }^{12}$. Enzymatic activity of $\alpha$-chymotrypsin ${ }^{7}$ and lysozyme ${ }^{6)}$ were each measured using milk casein and cells of Micrococcus lysodeikticus ATCC No.4698 (Sigma Chemical Co.) as substrates.

\section{$2 \cdot 3$ Chemical Modification of Functional} Groups of Active Degradation Products

Functional groups of the active degradation products obtained from oxd MLn were chemically modified by the method of Nakamura et $\mathrm{al}^{12) .14) .15}$. The active degradation products containing carbonyl and hydroxyl groups were converted to dimethylhydrazone (DMH) derivatives using $N$, $\mathrm{N}$-dimethylhydrazine (Nacalai Tesque, Inc.) and trimethylsilyl (TMS) ether derivatives using hexamethyldisilazane and trimethylchlorosilane (Nacalai Tesque, Inc.), respectively ${ }^{12.14)}$. Hydroperoxide(s) was reduced to hydroxyl group(s) using triphenylphosphine (TP, Wako Pure Chemical Ind., Ltd. ${ }^{15}$.

\section{Results}

\section{$3 \cdot 1$ Separation of Active Degradation Products from oxd MLn}

Figure 1 shows separation of oxd MLn and

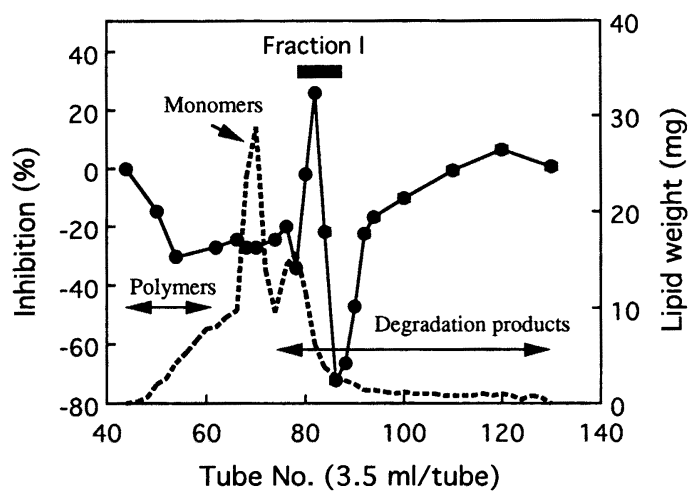

Fig. 1 Separation of Autoxidized Methyl Linolenate by Sephadex LH-20 and Inhibition of Amidase Activity of $\beta$-Trypsin by the Fractions Obtained. Column load : $420 \mathrm{mg}$ of oxd MLn.

- Inhibition, ….. Lipid weight.

inhibition of amidase activity of $\beta$-trypsin by the fractions obtained. The oxd MLn was separated into polymers, monomers, and degradation products ${ }^{11}$. Inhibitory activity of each fraction was assayed as follows. Each fraction, in which eluting solvent had been removed by evaporation under reduced pressure, was again dissolved in $1.0 \mathrm{ml}$ of EtOH. An aliquot $(20 \mu \mathrm{l})$ of the EtOH solution was added to $5 \mu \mathrm{g}$ of $\beta$-trypsin in $180 \mu \mathrm{l}$ of $0.1 \mathrm{M}$ Tris- $\mathrm{HCl}$ buffer ( $\mathrm{pH} 8.5$ ) containing $0.02 \mathrm{M} \mathrm{CaCl}_{2}$ and the mixture solution was incubated at $37^{\circ} \mathrm{C}$ for $90 \mathrm{~min}$. Then, the residual enzyme activity was measured using BAPNA as the amidase substrate $^{11) \sim 13}$. Among the fractions of degradation products, both inhibitory and potent acceleratory activities were observed around tube Nos. $78 \sim 81$ and $83 \sim 92$, respectively. Thus, the degradation products appeared to contain not only amidase accelerators, of which properties had already been reported $^{11) .12}$, but also inhibitors (tube Nos. $78 \sim 81$ indicated as Fraction I). In order to confirm the generation of these inhibitory substances during the autoxidation of MLn, the active degradation products (ADPs) were further separated from Fraction I by a silicic acid column chromatography $^{12)}$ (data not shown) and were used for subsequent experiments. The ADPs thus prepared were recovered about $0.2 \%$ from the starting MLn.

\section{$3 \cdot 2$ Characterization of Inhibitory Activity of ADPs}

Figure 2 shows the effect of conditions for reaction between the ADPs and $\beta$-trypsin on 

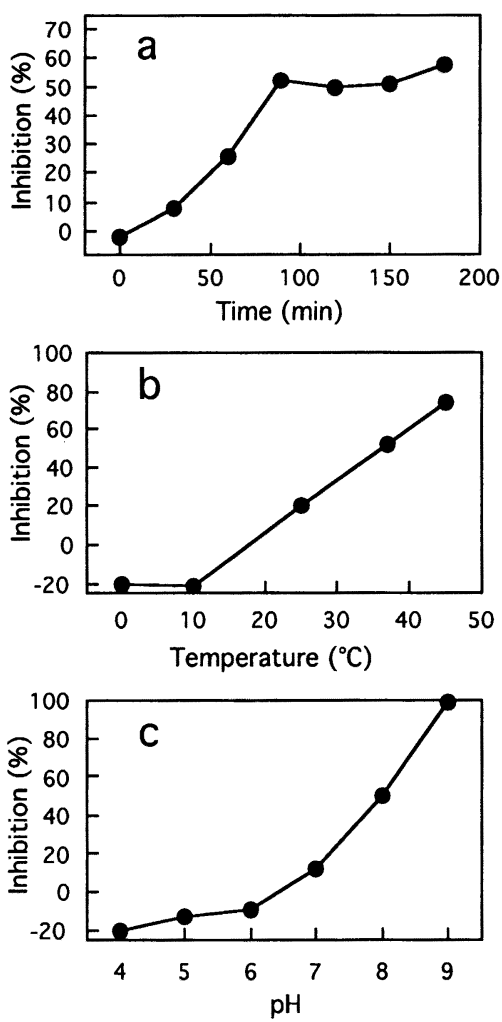

Fig. 2 Effect of Reaction Conditions between the ADPs and $\beta$-Trypsin on Inhibition of Amidase Activity of $\beta$-Trypsin.

Added amount : $\beta$-Trypsin $10 \mu \mathrm{g}$, ADPs $100 \mu \mathrm{g}$. Reaction condition : a, $\mathrm{pH} 8.0,37^{\circ} \mathrm{C} ; \mathrm{b}, \mathrm{pH} 8.0$, $90 \mathrm{~min} ; \mathrm{c}, 37^{\circ} \mathrm{C}, 90 \mathrm{~min}$.

inhibitory activity of the ADPs against amidase activity of $\beta$-trypsin. The inhibitory reaction was suggested to be dependent on all of reaction time, temperature, and $\mathrm{pH}$.

$\beta$-Trypsin shows not only amidase activity but also esterase and proteolytic activities ${ }^{16)}$. We had previously demonstrated that the amidase acceleratory substances, which were observed around tube Nos. 83 92 in Fig. 1, did not significantly influence the esterase and proteolytic activities of $\beta$-trypsin ${ }^{11}$. Therefore, the effect of the ADPs on these activities was examined (Fig. 3). Besides inhibiting the amidase activity, the ADPs could inhibit both esterase and proteolytic activities of $\beta$ trypsin, suggesting that $\beta$-trypsin is completely inactivated by the ADPs. The inhibitory substances are confirmed to be generated together with the acceleratory ones during the autoxidation of MLn.

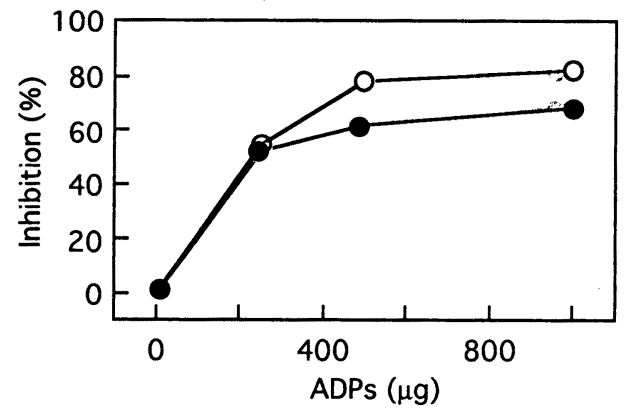

Fig. 3 Effect of the ADPs on Esterase and Proteolytic Activities of $\beta$-Trypsin.

Added amount : $\beta$-Trypsin : $10 \mu \mathrm{g}$. After reaction of the ADPs with $\beta$-trypsin in $10 \%$ EtOH-0.1 M Tris- $\mathrm{HCl}$ buffer $(\mathrm{pH} \mathrm{8.0)-0.02}$ $\mathrm{M} \mathrm{CaCl}_{2}$ at $37^{\circ} \mathrm{C}$ for $90 \mathrm{~min}$, aliquot of the reaction mixture was used for the assay of each enzymatic activity. Esterase activity, $\bigcirc$ Proteolytic activiy.

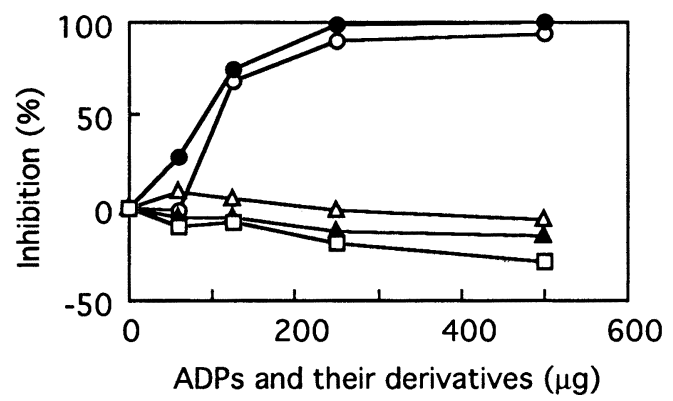

Fig. 4 Effect of Chemical Modification of Functional Groups of the ADPs and $\beta$-Trypsin on Inhibition of Amidase Activity.

Added amount : $\beta$-Trypsin, Acetylated trypsin $10 \mu \mathrm{g}$. Modification of functional groups : Carbonyl group $\rightarrow$ DMH, Hydroxyl group $\rightarrow$ TMS, Hydroperoxide $\rightarrow$ TP-treated ADPs : $\varepsilon$ Amino group of trypsin $\rightarrow$ Acetylated trypsin. $\bigcirc$ Control (ADPs $+\beta$-trypsin), $\triangle \mathrm{DMH}+\beta$ trypsin, $\square$ TMS $+\beta$-trypsin, $\bigcirc$ TP-treated ADPs $+\beta$-trypsin, $\Delta$ ADPs + Acetylated tryp$\sin$.

Figure 4 shows the effect of chemical modification of the functional groups of the ADPs and trypsin on the inhibition of amidase activity. By converting the carbonyl and hydroxyl groups of the ADPs into DMH and TMS ether derivatives, respectively, the inhibitory activities of the derivatives were markedly reduced. Both functional groups of the ADPs were demonstrated to be 


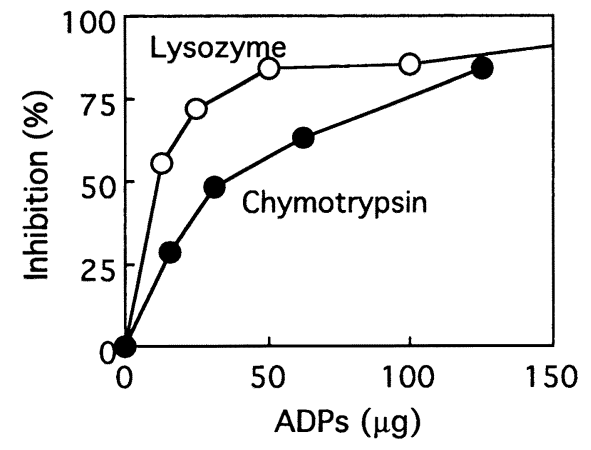

Fig. 5 Inhibitory Activity of the ADPs against Lysozyme and $\alpha$-Chymotrypsin Activities.

Reaction condition : Lysozyme $1 \mu \mathrm{g}, \mathrm{pH} 8.0,90$ $\min ; \alpha$-Chymotrypsin $25 \mu \mathrm{g}, \mathrm{pH} 8.0,30 \mathrm{~min}$.

essential for the occurrence of potent inhibition. However, the TP reduction of hydroperoxide(s) to hydroxyl group(s) did not significantly influence the original inhibitory activity of the ADPs. Needless to say, the completion of the TP reduction of hydroperoxide(s) had previously been ascertained by the HPLC analysis described by Nakamura and Maeda ${ }^{15}$. Thus, hydroperoxide(s), which has generally been supposed to be injurious to biological systems, was not always involved in the inhibitory activity of the ADPs. On the other hand, $\varepsilon$ - $N$-acetylated trypsin, of which all or most of the $\varepsilon$-amino groups had been substituted by acetylation $^{17)}$, was scarcely inhibited by the ADPs, suggesting that the inhibitory action will be associated with amino-carbonyl reaction between carbonyl group(s) of the ADPs and $\varepsilon$-amino group(s) of $\beta$-trypsin.

Inhibitory activity of the ADPs against other enzymes was examined as the reference samples to assess their injurious activity to biological systems. Figure 5 shows inhibitory activity of the ADPs against lysozyme and $\alpha$-chymotrypsin, both of which have often been used for evaluation of inhibitory activity of lipid oxidation products $^{4)(6) .18) .19)}$. The ADPs strongly inhibited both enzymatic activities as well as $\beta$-trypsin, suggesting that the ADPs will behave as inhibitors of various enzymes.

\section{Discussion}

Lipid oxidation products are well known to damage various kinds of enzymes and thereby inhibiting the activities. On the other hand, there is an exception that pepsin activity was stimulated by various oxidized products from unsaturated lipids such as linoleic acid ${ }^{7}$, safflower oil ${ }^{8)}$, and $M \mathbf{L n}^{20)}$. These reports are somewhat different from our studies that oxd MLn could behave as both inhibitor and accelerator of $\beta$-trypsin, while pepsin activity was accelerated but not fully inhibited by the autoxidized lipids.

In the previous paper ${ }^{11}$, the acceleration of amidase activity of $\beta$-trypsin was presumed to depend on the amino-carbonyl reaction between the carbonyl groups of the degradation products and $\varepsilon$-amino groups of $\beta$-trypsin. This reaction is in accordance with that observed in this study, suggesting that the degradation products will display both activities by forming adducts with $\beta$ trypsin in the similar mechanisms. However, it is unknown how the ADPs are able to inhibit $\beta$ trypsin while some other degradation products promote the amidase activity. In order to understand these interesting phenomena, it may provide the key to elucidate the structural similarities and differences between accelerators and inhibitors occurred during the autoxidation of MLn. The results of the chemical modification of functional groups of the ADPs suggest that the inhibitory substances would be hydroxycarbonyl analogs, which are known to be generated during the autoxidation of polyunsaturated fatty acids ${ }^{1 / .11)(14)}$. However, our finding inhibitory substances originating from $\omega 3$ polyunsaturated fatty acid MLn must be different from 4-hydroxynonenal, the notorious major toxic hydroxyaldehyde, formed through peroxidation of $\omega 6$ polyunsaturated fatty acids such as arachidonic and linoleic acids ${ }^{1 / 3)}$. Thus, the exact structures of the inhibitory substances in the ADPs are now under investigations in our laboratories.

(Received Apr. 21, 1999 ; Accepted Jun. 18, 1999)

\section{References}

1) A. Benedetti, M. Comporti, H. Esterbauer, Biochim. Biophys. Acta, 620, 281 (1980).

2) A. Benedetti, R. Fulceri, M. Comporti, Biochim. Biophys. Acta, 793, 489 (1984).

3) J. Chen, S. Schenker, T.A. Frosto, G.I. Henderson, Biochim. Biophys. Acta, 1380, 336 (1998).

4) K.S. Chio, A.L. Tappel, Biochemisty, 8, 2827 (1969).

5) S. Matsushita, J. Agr. Food Chem., 23, 150 (1975).

6) J. Kanner, M. Karel, J. Agr. Food Chem., 24, 468 
(1976).

7) S. Matsushita, M. Kobayashi, Agr. Biol. Chem., 34, 825 (1970).

8) M. Yoshioka, K. Suzuki, T. Kaneda, J. Japan. Oil Chem. Soc., 21, 881 (1972).

9) H. Chen, A.L. Tappel, Lipids, 31, 47 (1996).

10) H. Hatate, M. Toyomizu, Bull. Japan. Soc. Sci. Fish., 51, 627 (1985).

11) H. Hatate, T. Nakamura, J. Japan. Oil Chem. Soc., 35, 1014 (1986).

12) H. Hatate, T. Nakamura, J. Japan. Oil Chem. Soc., 36, 210 (1987).

13) D.D. Schroeder, E. Shaw, J. Biol. Chem., 243, 2943 (1968).
14) T. Nakamura, N. Uekihara, M. Toyomizu, Bull. Japan. Soc. Sci. Fish., 45, 107 (1979).

15) T. Nakamura, H. Maeda, Lipids, 26, 765 (1991).

16) K. A. Walsh, in "Methods in Enzymology," eds. by G.E. Perlmann, L. Lorand, Vol. 19, Acad. Press, New York (1977) p.41.

17) J. Labouesse, M. Gervais, European J. Biochem., 2, 215 (1967).

18) W.T. Roubal, A.L. Tappel, Arch. Biochem. Biophys., 113, 5 (1966).

19) M. Karel, K. Schaich, R.B. Roy, J. Agr. Food Chem., 23, 159 (1975).

20) H. Hatate, T. Iribe, M. Kochi, J. Shimonoseki Univ. Fish., 37, 113 (1989). 


\section{[ノート］リルレン酸メチルの自動酸化中におけるトリプシン阻害 および促進物質の同時発現}

\section{ートリプシン阻害物質の確認一}

幡手 英 雄 ${ }^{* 1}$ - 濱 洋一郎 ${ }^{* 2}$ - 田中 竜 介 $^{* 1}$

鈴木 喜隆*1 . 幡手泰 雄*3 . 河 野 恵 宣*4

*1 水産大学校食品化学科 ( $\bar{\top} 759-6595$ 下関市永田本町 2-7-1)

$* 2$ 佐賀大学農学部応用生物科学科 ( $\mathrm{T}$ 840-8502 佐賀市本庄町 1)

*3 鹿児島大学工学部応用化学工学科 ( T 890-0065 鹿児島市郡元 1-21-40)

*4 宮崎大学工学部物質工学科 ( $\mathrm{T}$ 889-2192 宮崎市学園木花台西 1-1)

リノレン酸メチルの自動酸化中にß-トリプシン活性を阻害する一群の分解生成物が，すでに明らかにされてい るトリプシンのアミダーゼ活性促進物質ととも形成されていることがわかった。阻害作用の発現にはこれら分解生 成物のカルボニル基と水酸基ならびにトリプシンの しも関与してないことを官能基の化学修飾実験で示した。このトリプシン阻害活性をもつ分解生成物はリゾチーム や $\alpha$-キモトリプシン活性を強く阻害したことから，各種䣲素に対しても阻害物質として作用しうることが推察さ れた。これらのことは不飢和脂質の自動酸化中に各種酵素の阻害物質や促進物質が同時に形成される可能性を示唆 している。

(連絡者：幡手英雄）Vol.48，No.9，917（1999）

[速報］ポリエチレングリコール鎖を結合させたリン脂質を含む

\section{リポソームのフリーズフラクチャー法による電顕写真}

橋崎 要*1,*2 . 伊藤 智 桂*3 . 酒井 秀樹*1,*4 . 横山祥子*5

田口博之 $之^{* 2}$. 斎藤好廣*2 . 小川尚武*2 . 阿部正彦*1,*4

*1 東京理科大学理工学部 ( $=278-8510$ 千葉県野田市山崎 2641)

*2 日本大学薬学部 ( ⿳ 274-8555 千葉県船橋市習志野台 7-7-1)

*3 日本油脂油化学研究所 ( $=210-0865$ 神奈川県川崎市川崎区干鳥町 3-3)

*4 東京理科大学界面科学研究所 (广 162-0825 東京都新宿区神楽坂 1-3)

*5 共立薬科大学 ( ₹ 105-8512 東京都港区芝公園 1-5-30)

ジステアロイル-N-モノメトキシーポリエチレングリコールースクシニル - フォスファチジルエタノールアミン (PEG-DSPE) を含むジパルミトイルフォスファチジルコリン (DPPC) リポソームのフリーズフラクチャー法による 電顕写真を撮影した。DPPC二分子膜の主相転移温度と前転移温度の間の温度から急速凍結させた上記リポソーム の割断面には帯状構造の他に平面構造も存在していたことからリポソーム内での相分離が示唆された。

(連絡者：阿部正彦) Vol.48, No.9, 923 (1999) 